\title{
Estimation of Input of Unintentionally Produced Persistent Organic Pollutants into the Air Basin of the Odessa Industrial-and-Urban Agglomeration
}

\author{
Vladyslav I. Mykhailenko ${ }^{1 *}$, Tamerlan A. Safranov ${ }^{1}$ \\ 1 Department of Ecology and Environmental Protection of Odessa State Environmental University, Lvivska Str. \\ 15, 65016, Odessa, Ukraine \\ * Corresponding author's e-mail: vladislav.mykhailenko@gmail.com
}

\begin{abstract}
The environmental legislation in Ukraine is changing rapidly. These changes are related to the adaptation of Ukrainian laws to the requirements of the European Union. In this regard, the paper considers the unintentional production of Persistent Organic Pollutants (POPs) in the Odessa Industrial-and-Urban Agglomeration (next - Odessa agglomeration) in the context of new regulatory and legal requirements of Ukraine. In many countries around the world, the issue of pollution of environmental components by POPs has a large focus, because POPs pose a global threat to the environment and human health. The work aims to assess the main sources of unintentional production of POPs in the Odessa agglomeration during one year (2017), taking into account the new territorial features of the Odessa agglomeration. For the first time for Odessa agglomeration, the mass of POPs formed by main sources using the newest European methodological approach was calculated, sources of unintentional production of POPs on volumes of these substances were ranked, and their total mass of generation on the territory of Odessa agglomeration was calculated. The number of POPs molecules equivalent to 2,3,7,8-TCDD, which infiltrate into the air basin of the Odessa agglomeration, hence into the organisms of the agglomeration inhabitants, was calculated. The obtained results were compared with the allowable number per capita of the agglomeration, the relevant conclusions were drawn. Priority sources of unintentional production of POPs were identified, which allows taking appropriate preventive measures to reduce the scale of their generation.
\end{abstract}

Keywords: persistent organic pollutants, generation, pollution sources, emission factor.

\section{INTRODUCTION}

Real-time monitoring of air pollution [Chugai et al., 2020] and surface watercourses [Odnorih et al., 2020; Sakalova et al., 2019] and scientifically grounded analysis of the data of this monitoring is a prerequisite for developing a strategy of management and technical measures to ensure environmental safety territories. To a large extent, this applies to the Odessa Industrial-and-Urban Agglomeration (next - Odessa agglomeration).

The Odessa agglomeration is a strategically important part of Ukraine, its first and oldest historically formed agglomeration. For a long time, the Odessa agglomeration was defined as a subregion of the Odessa region, also called
"Greater Odessa Area", delineated by the administrative boundaries of the cities of regional importance (Odessa, Chernomorsk, Teplodar and Yuzhne) and three districts of Odessa region (Bilyaevsky, Kominternovsky and Ovidiopolsky) [Pletos, 2017]. However, according to the changes in the Ukrainian legislation [Ukrainian Ministry, 2019], the definition and territorial boundaries of the Odessa agglomeration was changed. Since 2019, the term "agglomeration" is defined as an "area with a population of over 250 thousand people, which is separately identified for the purposes monitoring and managing air quality". Thus, in accordance with the requirements of the updated legislation of Ukraine, the Odessa agglomeration 


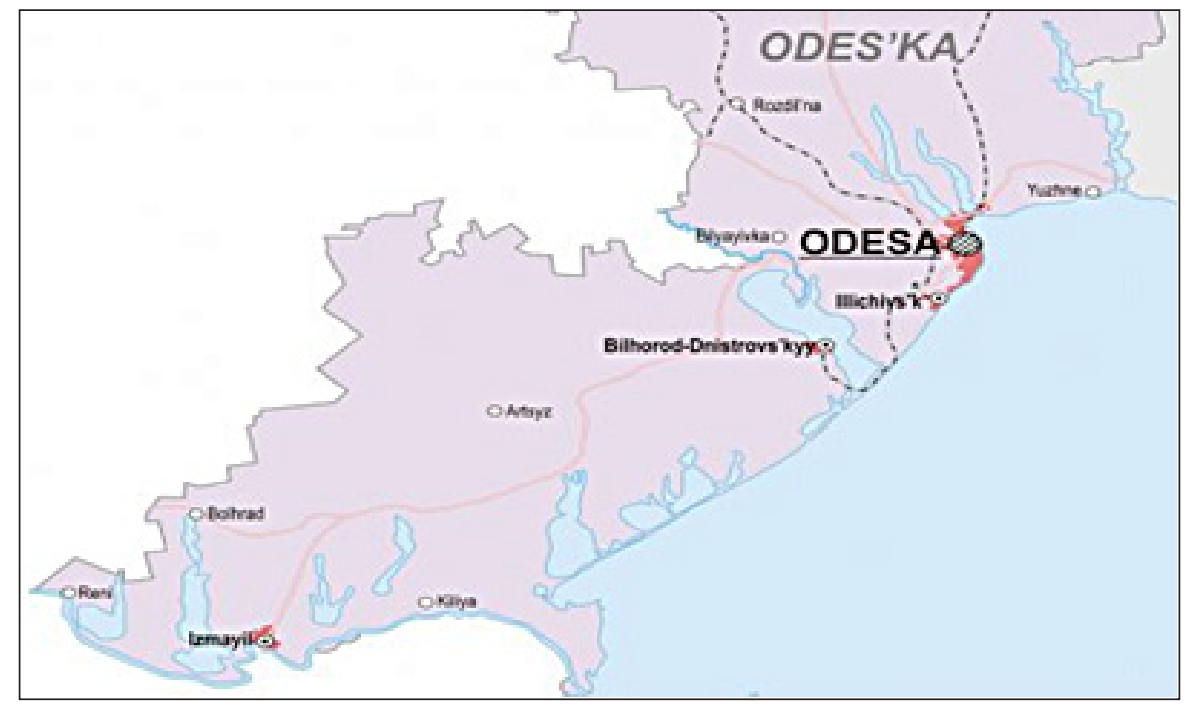

Figure 1. Map of the study region

is limited to the territory of Odessa, which is taken into account in this work. A fragment of the map of the Odessa region, where the Odessa agglomeration is located, is shown in Figure 1.

This approach is strategically important in the context of dynamic changes in Ukrainian legislation in the field of air quality monitoring and adaptation of methodological framework of air monitoring to European legislation. In the European Union, significant research is devoted to the environmental pollution by Persistent Organic Pollutants (POPs) [Akhtar et al., 2021; Jeno et al., 2021; Gusev et al., 2015; Xu et al., 2013].

It is known that POPs pose a serious global threat to the environment and human health [IARC, 2012]. Usually, when considering POPs, the most dangerous of the representatives of these substances are mentioned - 2,3,7,8-tetrapara-dibenzo-p-dioxin (or 2,3,7,8-TCDD), which according to the modern investigation of «International Agency for Research on Cancer» refers to Group 1 - substances that are carcinogenic to humans [IARC, 2020].

Despite the large variety of POPs, they all have common properties, such as resistance to decomposition, extreme toxicity even at very low concentrations, abilities to bioaccumulate, transboundary transfer and deposition [VanEtten S.L. et al., 2020; Treger, 2011].

The main international legal act establishing the norms on the environmental protection and population health from the effects of POPs is the Stockholm Convention, which was adopted on May 22, 2001 and ratified in Ukraine in 2007. According to this convention, all POPs can be divided into 2 groups: 1 ) obtained intentionally for direct use (pesticides, industrial products); 2) produced unintentionally (fuel combustion products, by-products of technological processes, etc.).

Unfortunately, in Ukraine there is no separate legislation base for POPs. All norms and rules regulating the formation of these pollutants are included in a large number of legislative acts, which does not allow systematizing and specifying actions in the field of POPs management. At the same time, it should be noted that in Ukraine there is no POPs monitoring system, as well as any systematic and accessible statistical information, which makes it impossible to calculate POPs formation from some sources.

The aim of the work was to assess the main sources of unintentional production of POPs in the Odessa agglomeration during 2017, since the statistical information for this period is the most available in the public access at the time of the study.

\section{MATERIALS AND METHODS}

The work considers the problem of unintentional production of POPs in the Odessa agglomeration during a separate year (2017). For the first time, the main sources and volumes of unintentional production of POPs in Odessa agglomeration were established in accordance with the new normative-legislative documents of Ukraine. It should be noted that the study was conducted taking into account the new requirements of atmospheric monitoring and the new territorial boundaries of the Odessa agglomeration. 
Throughout the course of the study, it was discovered that the main sources of unintentional production of POPs in the Odessa agglomeration are combustion of organic fuel by stationary and mobile sources, production of building materials, functioning of crematoria, smoking of tobacco products, waste deposits and functioning of municipal wastewater treatment plants. Unfortunately, due to the lack of source data, it is impossible to calculate the formation of POPs for the combustion of organic fuel by stationary sources. Significant, not yet evaluated POPs are released as a result of biodegradation of blue-green algae, the rapid uncontrolled development of which is observed under the conditions of surface water pollution by phosphorus and nitrogen compounds and general warming of these reservoirs as a result of climate change [Nykyforov et al., 2016; Malovanyy et al., 2016].

The latest European methods in updated versions were used to calculate the unintentional production of POPs in the Odessa agglomeration [EMEP/EEA, 2019; UNEP, 2013]. Typically, one of these methods is used for POPs emission inventorization, but the authors of this paper used the emission factors presented in both methods to obtain more complete results.

The emission factor is an experimentally established numerical characteristic of a specific source of unintentional production of POPs, which shows the mass of formation of these substances per unit mass of raw materials used in the process or manufactured products. Unintentional production of POPs using these coefficients is calculated by the formula:

$$
\begin{aligned}
& \mathrm{E}_{\mathrm{POPs}}=\mathrm{M}_{\text {materials }} \cdot \mathrm{EF}_{\text {pollutant }} \\
& \text { or } \mathrm{E}_{\mathrm{POPs}}=\mathrm{M}_{\text {products }} \cdot \mathrm{EF}_{\text {pollutant }}
\end{aligned}
$$

where: $\mathrm{E}_{\mathrm{POPs}}$ - emissions of POPs in unit mass; $\mathrm{M}_{\text {product }}$ - mass of products (the technological process of their production involves the unintentional production of POPs); $\mathrm{M}_{\text {material }}$ - mass of raw materials, the technological process of production of which involves the unintentional production of POPs; $\mathrm{EF}_{\text {pollutant }}$ - emission factor of pollutant.

The analysis of calculation methods showed that, unfortunately, even the use of two methods of POPs calculation does not allow fully assessing the specifics of the formation and environmental release of these pollutants.
The method [EMEP/EEA, 2019] provides for the calculation of a wide range of pollutants being the only possible way to calculate the formation of not only such POPs as polychlorinated dibenzon-dioxins (PCDD) and polychlorinated dibenzofurans (PCDF), but also polychlorinated biphenyls (PCBs) and hexachlorobenzene HCB. The disadvantage of this method is the lack of emission factors for most types of industries, which makes the sole use of this method ineffective for a comprehensive assessment of unintentional production of POPs within the agglomeration. Moreover, the method allows calculating only the emission of POPs into the air basin, without taking into account their distribution in other natural environments.

Method [UNEP, 2013] allows calculating the formation of only PCDD + PCDF (next $\mathrm{PCDD} / \mathrm{F}$ ). Especially for some of the industries, the coefficients that allow taking into account the redistribution of $\mathrm{PCDD} / \mathrm{F}$ in the environments are presented in this method that helps to estimate the degree of negative influence more precisely. Unfortunately, in the considered case, the complete redistribution in natural environments was calculated only for the production of bricks and asphalt.

Moreover, a characteristic feature of the methods used involves the units of measurement of POPs in the calculation results. The result using the method [EMEP/EEA, 2019] is obtained in $\mathrm{g}$, whereas according to the method [UNEP, 2013] it is retrieved in the mass of the pollutant in $g$ of the toxicological equivalent of PCDD/F, (TEQ PCDD/F), which are not the same units.

Toxicological (dioxin) equivalent is a value that expresses the cumulative toxicity of complex mixtures of PCDD/F due to the toxicity of $2,3,7,8$-TCDD. This unit of measurement is used to facilitate the procedure of estimating the concentrations of substances in this group.

This is why the conversion of the results to the one unit of the measurement is a matter of huge importance. According to [Shelepchikov, 2010], the toxicity of any mixture of PCDD/F can be expressed through the toxicity of 2,3,7,8-TCDD, taken in an equivalent toxicity. Thus, all the results of PCDD/F calculations can be converted into g TEQ 2,3,7,8-TCDD (or g TEQ). Coefficient 1 is used to convert $r$ TEQ PCDD/F to TEQ 2,3,7,8-TCDD.

In addition, using the information given in [NAS, 2004], with some error, g PCB can be converted to $g$ TEQ TE through the most commonly used TEQ for PCB, which is equal to 0.0005 . Similarly, using the value of the coefficient 0.0001 
given in [NAS, 2004], the value of $\mathrm{g} \mathrm{HCB}$ can be converted into the value of $g$ TEQ.

Thus, all the results obtained are presented in one unit of measurement, which allowed fully using both methods to obtain a more complete picture of the input of unintentionally produced POPs into the environment of the Odessa agglomeration.

\section{RESULTS AND DISCUSSION}

\section{Unintentional production of POPs during combustion of organic fuel by mobile sources}

The emission of unintentionally produced POPs in the combustion products of organic fuel in the Odessa agglomeration should be considered from two types of man-made sources: stationary and mobile. Due to incomplete statistical information, the calculation was performed only for mobile sources. The emissions from mobile sources included the formation of POPs during the combustion of gasoline and diesel fuel.

Same as in all combustion processes, POPs are formed after the end of the process of combustion and cooling of stack gases. That is why the emissions of dioxins and furans largely depend on the cooling conditions of flue gases and stack gases. Residual soot particulates, as well as chlorine contained in the coal, recombine in the presence of metal chlorides as catalysts with the formation of POPs. The main routes of entry into the environment are emissions into the air basin, especially as part of fly ash.

On the basis of the information sources [EMEP/EEA, 2019; UNEP, 2013; Head of Department of Statistics in the Odessa region, 2017; Kopytov, 2012; Conversion calculator, 2021], the gross unintentional emissions of POPs from mobile sources of the Odessa agglomeration in 2017 were calculated using the appropriate volumes of fuel. According to the results of the calculation, the formation of POPs for mobile sources was $0.22 \mathrm{~g}$ TEQ (Table 1).

The reason for performing calculations for only one pollutant is that the calculation method [UNEP, 2013] allows determining only the unintentional production of $\mathrm{PCDD} / \mathrm{F}$.

\section{Unintentional production of POPs in the production of building materials}

\section{Brick production}

According to [UNEP, 2013], throughout the process of bricks production, POPs enter the environment in three directions: 1) emission into the air as part of the gas-air mixture; 2) output along with the products; 3 ) emissions from waste as carriers of POPs. Each of these directions has its own emission factor (EF).

On the basis of [Dukat LV, 2021; LLC "Stroykeramika", 2021; GreenBud, 2021], it was established that 18 million units of conventional bricks were produced in the Odessa agglomeration in 2017, which is 63,000 tons in terms of weight.

Using the method [Ministry of Environmental Protection and Natural Resources of the Republic of Tatarstan, 1997], the mass of brick production residue (scrap brick) was calculated according to the formula:

$$
M_{\text {waste }}=B \cdot \Pi_{\mathrm{y} i}
$$

where: $M_{\text {waste }}$ - the amount of scrap brick generated during production; $\Pi_{y i}-$ specific quantity factor of waste, generated by 1 million bricks (for firing bricks, this figure is $76,000 \mathrm{~kg}$ per 1 million bricks).

On the basis of the above, the formation of PCDD/F in 2017 in three directions was calculated. Thus, as part of the gas-air mixture the environment achieves PCDD/F - 0.013 g TEQ, $\mathrm{PCDD} / \mathrm{F}$ in the product $-3.78 \cdot 10^{-3} \mathrm{~g}$ TEQ, $\mathrm{PCDD} / \mathrm{F}$ in the scrap brick $-0.27 \cdot 10^{-4} \mathrm{~g}$ TEQ (see Table 1). The obtained calculations illustrate that the largest amount of PCDD/F enters the air basin as part of the gas-air mixture and is distributed in the air. Moreover, a significant amount of POPs is released into the environment as part of manufactured products, which could have a negative impact on the health of the urban population. At the same time, a part of the PCDD/F enters the ground cover as part of the scrap brick and has a concentrated action in space.

\section{Cement production}

The only producer of cement in the Odessa agglomeration is the Odessa Cement Plant, the annual production of which is 550000 tons per year [Odessa Cement Plant, 2021]. 
Table 1. Unintentional production of Persistent Organic Pollutants in the Odessa Industrial-And-Urban Agglomeration in 2017

\begin{tabular}{|c|c|c|c|c|c|c|c|c|}
\hline \multicolumn{3}{|c|}{ Source } & \multicolumn{6}{|c|}{ Production of POPs (with direction) } \\
\hline \multirow{2}{*}{ Name } & \multirow{2}{*}{ Number } & \multirow{2}{*}{ Units } & \multirow{2}{*}{$\frac{\text { PCB }}{\text { Air }}$} & \multirow{2}{*}{$\frac{\mathrm{HCB}}{\mathrm{Air}}$} & \multicolumn{3}{|c|}{$\mathrm{PCDD} / \mathrm{F}$. } & \multirow{2}{*}{ Units } \\
\hline & & & & & Air & Product & Balance & \\
\hline \multicolumn{9}{|c|}{ Combustion of organic fuel (mobile sources) } \\
\hline Gasoline & 136400 & TFOE & - & - & 0.210 & - & - & g TEQ \\
\hline Diesel fuel & 150500 & TFOE & - & - & 0.010 & - & - & g TEQ \\
\hline \multicolumn{9}{|c|}{ Production of building materials } \\
\hline Brick & 63000 & $10^{3} \mathrm{t}$ & - & - & 0.013 & $3.78^{*} 10^{-3}$ & $0.27 * 10^{-4}$ & g TEQ \\
\hline Cement & 550000 & $\mathrm{t}$ & 56.65 & 2.53 & 2.3 & - & - & g \\
\hline Asphalt & 1017.3 & $10^{3} \mathrm{t}$ & - & - & 0.101 & - & - & g TEQ \\
\hline \multicolumn{9}{|c|}{ Waste deposits } \\
\hline $\begin{array}{l}\text { Municipal } \\
\text { Solid Waste }\end{array}$ & 674100 & $\mathrm{t}$ & - & - & - & 0.34 & 33.71 & g TEQ \\
\hline \multicolumn{9}{|c|}{ Functioning of crematoria } \\
\hline $\begin{array}{l}\text { Number of } \\
\text { cremated }\end{array}$ & 3900 & people & 1.59 & 0.59 & $0.12^{*} 10^{-3}$ & - & - & g TEQ \\
\hline \multicolumn{9}{|c|}{ Smoking tobacco products } \\
\hline Cigarettes & $1113^{*} 10^{6}$ & cigarettes & - & - & $0.12^{*} 10^{-3}$ & - & $0.12^{*} 10^{-3}$ & g TEQ \\
\hline \multicolumn{9}{|c|}{ Functioning of municipal sewage treatment plants } \\
\hline Treated SW & 83.2 & bln, $\mathrm{dm}^{3}$ & - & - & - & 0.832 & 1.116 & g TEQ \\
\hline Untreated SW & 10.3 & bln, $\mathrm{dm}^{3}$ & - & - & - & 0.052 & 0 & g TEQ \\
\hline
\end{tabular}

In cement production, the technological process causing POPs formation is clinker burning due to the high-temperature behavior of the operation.

Using the methods [EMEP/EEA, 2019; UNEP, 2013], the formation of POPs in cement production was determined, which was: $\mathrm{PCB}-56.56 \mathrm{~g}$, $\mathrm{HCB}-2.53 \mathrm{~g}$ and $\mathrm{PCDD} / \mathrm{F}-2.75 \mathrm{~g}$ (see Table 1).

It should be noted that throughout the process of cement production POPs input only into the air basin, which is taken into account in calculation.

\section{Asphalt production}

The industrial site of the asphalt plant, as a rule, includes a section for the preparation of organic binder and asphalt concrete, a section for the preparation of mineral materials and boilerhouse. Most often at the same place is a section for the preparation of road bituminous binder from raw materials (tar), bitumen emulsions, fortified soils, brick crushing-and-sorting plants [Kapushko, 2012].

The production of asphalt concrete can be considered conditionally waste-free, as the dust in asphalt concrete production can be completely reused [The Ministry of Environmental Protection of the Republic of Kazakhstan, 2008]. That is why the formed POPs in the production of asphalt are contained only in the gas-air mixture.
On the basis of the official data provided to us [Head of the Department of Statistics in the Odessa region, 2017], the production of asphalt in the Odessa agglomeration in 2017 was estimated, which amounted to 1017.3 thousand tons. Using [UNEP, 2013], the production of PCDD/F was determined, which amounted to $0.101 \mathrm{~g}$ TEQ.

Thus, the total amount of POPs that enters the environment from building production is $2.864 \mathrm{~g}$ TEQ - PCDD/F, $56.65 \mathrm{~g}-\mathrm{PCB}$ and $2.53 \mathrm{~g}-\mathrm{HCB}$.

After analyzing the obtained results, a histogram of the distribution of POPs in the environment in the appropriate areas for this category was built, the results are presented in Figure 2.

As can be seen from Figure 2, the production of cement and asphalt is a source of unidirectional impact on the environment. In turn, brick production affects all natural components of the Odessa agglomeration environment, but cement production generates a much larger amount of POPs than asphalt and brick production.

\section{Unintentional production of POPs during ground storage of Municipal Solid Waste}

Municipal solid waste (MSW) is a potential source of unintentional production of POPs due to their diverse morphological composition, in 


\section{$\square$ Air $\square$ Product $\square$ Balance}

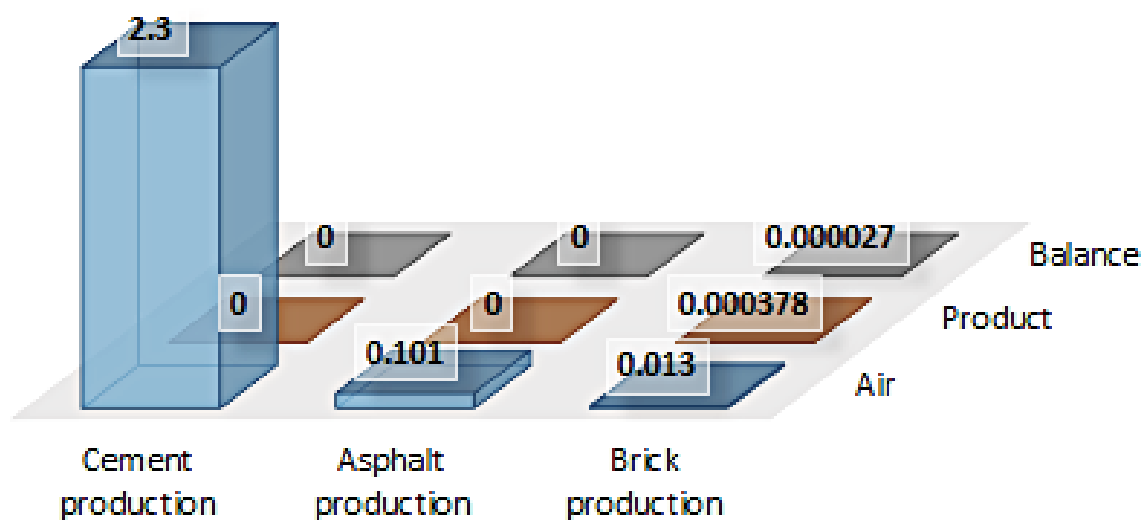

Figure 2. Distribution of POPs entry into the environment of Odessa agglomeration in the production of building materials by areas

particular - the presence of chlorine-containing components. The presence of chlorine is ensured by the fact that municipal solid waste contains mainly medical waste in the composition of antiseptics and plastics, which modern syringes and household items are made of. Moreover, a large contribution to the increased content of chlorinecontaining components in MSW is made by PVC materials, which come as part of building waste (stretch ceilings, linoleum, heat-resistant plastics, etc.) and shoe plastics. The presence of heavy metals in batteries, accumulators and other electrical and electronic equipment accelerates the formation of $\mathrm{PCDD} / \mathrm{F}$.

According to [Head of the Department of Statistics in the Odessa region, 2017], 100\% of the waste generated in the Odessa agglomeration is discarded on landfills. According to the Department of Life Support Systems and Energy Efficiency of the Odessa Regional State Administration, there are 628 landfills in the region (including 58 - overloaded, 104 - do not meet the standards of sanitary-epidemiological and environmental safety). The Odessa region ranks first among the regions of Ukraine in the area occupied by landfills (over 1040 hectares).

Using the data [UNEP, 2013; Head of the Department of Statistics in the Odessa region, 2017], we calculated the amount of PCDD/F, which is formed due to the removal of MSW Odessa agglomeration. It should be noted that the entry of $\mathrm{PCDD} / \mathrm{F}$ into the environment in this case goes in two ways: in water - as part of the filtrate and the residue that accumulates in the body of the landfill.

The mass of waste generated in the Odessa agglomeration in 2017 amounted to 674.1 thousand tons, and the corresponding reception of $\mathrm{PCDD} / \mathrm{F}$ in the environment: $0.34 \mathrm{~g}$ TEQ - PCDD/F in the filtrate and $33.71 \mathrm{~g}$ TEQ - PCDD/F in the composition of the residue that accumulates in the body of the landfill (Table 1). The scheme of POPs input into the environment of Odessa agglomeration is given in Figure 3.

The calculations show that in the latter case, the inflow of PCDD/F into the environment is 100 times greater. This can be explained by the fact that before entering the water, the filtrate undergoes some kind of a purification process through the rocks of the aeration zone, which it passes through before entering the soil aquifer.

\section{Unintentional production of POPs during the operation of crematoria}

Recently, the issue of cremation of dead bodies is increasingly arising because of the problems with land for the burial of the dead and the efficiency of this type of disposal. Cremation - burning of the dead bodies to ashes - is a potential source of POPs.

According to [religion.in.ua], 30\% of the families of the dead in Odessa turn to crematoria. According to the Statistical Yearbook of Odessa region, the number of deaths in Odessa in 2017 was 


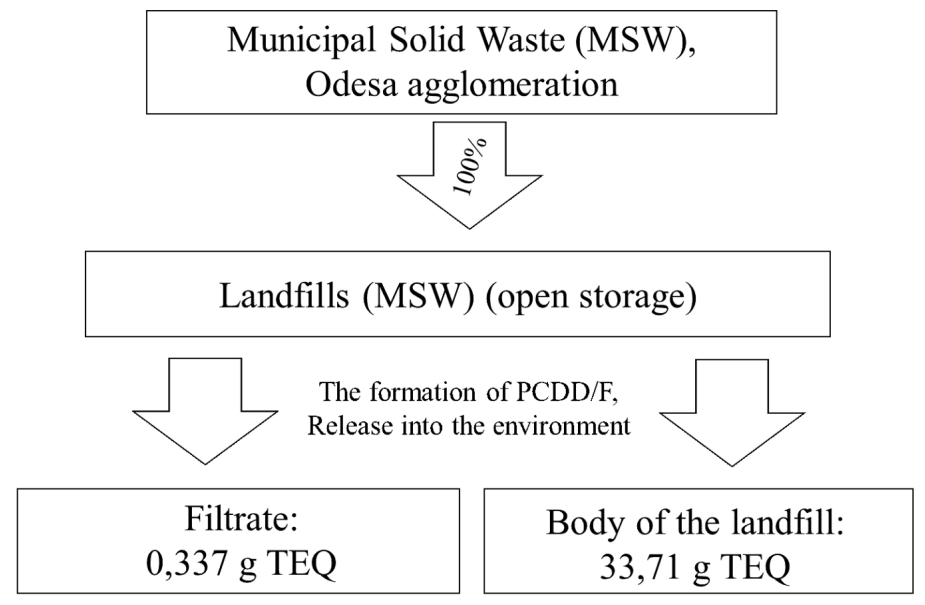

Figure 3. The scheme of POPs input into the environment of the Odessa agglomeration

13,000 people. A calculation was performed and it was established that the mass of unintentionally formed POPs in this direction was: PCDD/F -0.12 mg TEQ, PCB $-1.6 \mathrm{~g}$ TEQ, HCB $-0.59 \mathrm{~g}$ TEQ (see Table. 1).

\section{Unintentional production of POPs from smoking of tobacco products}

Smoking tobacco products burns organic matter, which is a source of unintentional production of POPs. In addition, the danger of exposure to POPs while smoking is that a significant part of the formed substances enters directly into the body of the smoker and all the other people around him. Smoking is especially dangerous for pregnant women, as POPs accumulate in breast milk and are passed from a mother to a child.

On the basis of the information [zn.ua], it was found that the number of smokers in Odessa is $20.1 \%$ of all residents, and the number of cigarettes smoked averages 15 cigarettes/(person per day). Thus, the mass of PCDD/F was $0.12 \mathrm{mg}$ in atmospheric air and $0.12 \mathrm{mg}$ in the ash residue (see Table 1).

\section{Unintentional production of POPs during the operation of municipal wastewater treatment plants}

Sewage effluents are wastes that contain substances dissolved in water and/or suspended solids. In general, sewage waters are characterized by a low value of PCDD/F, but when they are disinfected with chlorine, the concentrations of these substances increase rapidly, sometimes up to 50 times. Other factors, such as laundry and textiles that have been treated with paints and pesticides containing $\mathrm{PCDD} / \mathrm{F}$, may be the cause the presence of these substances in sewage waters. PCDD/F can also be included in sewage waters with runoff or precipitation that contain atmospheric emissions of POPs from combustion sources or as part of untreated industrial wastewater.

The source of $\mathrm{PCDD} / \mathrm{F}$ is also activated sludge. In addition, the treatment of activated sludge can lead to their formation. For example, the distribution of activated sludge in irrigated fields can lead to increased PCDD/F concentrations in soils, in future plants which will grow in these areas, and in the tissues of the animals fed on irrigated fields. The activated sludge that has been buried in cemeteries may also contribute to the formation of PCDD/F in the filtrate. It should be noted that PCDD/F can be formed at thermal drying stations of activated sludge.

Note that the category of sewage waters includes the effluents from urban areas that flow into treatment plants.

Sewage waters discharge into open water is the practice of discharging untreated sewage waters or other waste directly into open water bodies - rivers, lakes and oceans. The sources of PCDD/F in this case are the same as in sewage waters. That is, due to the lack of a sufficient sewage waters treatment, $\mathrm{PCDD} / \mathrm{F}$ input the water body as a part of the sewage waters in full. There is no activated sludge containing PCDD/F in this case.

Using the information [State Committee of the Russian Federation for Environmental Protection, 1999], the formation of PCDD/F during the operation of the municipal sewage treatment plants of the Odessa agglomeration in 2017 was determined. As a result of sewage waters discharge into the water bodies: $0.832 \mathrm{~g}$ of TEQ 


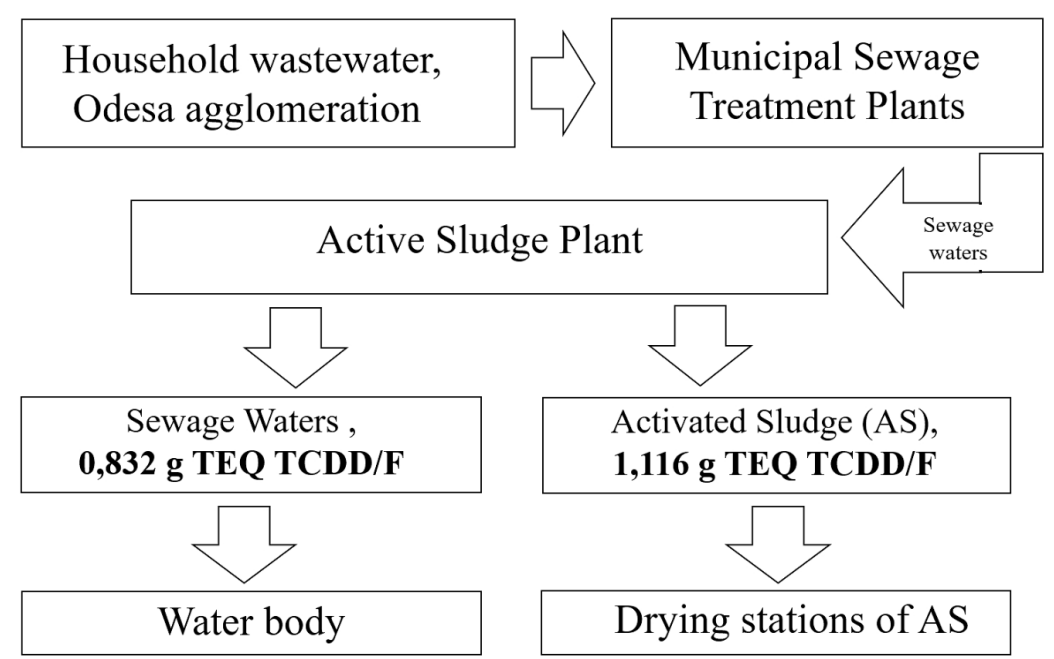

Figure 4. The scheme of POPs entry into the environment with treated sewage

$\mathrm{PCDD} / \mathrm{F}$ come in the composition of sewage waters and $1.166 \mathrm{~g}$ of TEQ PCDD/F in the composition of activated sludge. As a result of direct sewage water discharge, $0.052 \mathrm{~g}$ TE PCDD/F enters water bodies (see Table 1). The scheme of POPs entry into the environment with treated sewage is presented in Figure 4.

The generalized results of calculations were presented in Table 1. While analyzing the completeness of statistical data for 2017 compared to 2012 [Head of the Department of Statistics in the Odessa region, 2012], when the information provided was more complete, it can be concluded that there was a significant limitation of the completeness of the source information, which dramatically affected the results. Thus, on the one hand, the largest contribution is made by landfill storing of solid waste, and the lack of calculation results for such sources as smokehouses, stationary fuel combustion, fuel oil combustion by stationary sources, lime production does not significantly affect the calculation POPs formation, but for such supertecotoxicants as $\mathrm{PCDD} / \mathrm{F}, \mathrm{PCB}$ and $\mathrm{HCB}$, even these masses of substances are essential. Moreover, the lack of information on certain sources of pollution is strategically unacceptable, because the knowledge of contribution of all available pollution sources is necessary for the effective reduction of the unintentional POPs production.

The next step for an approximate assessment of the impact of POP, the number of molecules per 1 inhabitant of the Odessa agglomeration was calculated (see Table 2).

Next, the number of molecules that is acceptable for entry into the human body through the respiratory system (using the admissible concentration limit) was determined, which was $6.6 \cdot 10^{12} \mathrm{~mol} /($ person $\cdot y e a r)$. For this purpose, the sources of POPs input into the atmosphere were identified and the volumes of inflow of these substances into the city air basin were determined (Fig. 5).

Using Table 1 and the coefficients above, the number of molecules of 2,3,7,8-TCDD,

Table 2. The total mass and number of molecules 2,3,7,8-TCDD, unintentionally formed in the Odessa agglomeration in 2017

\begin{tabular}{|c|c|c|c|c|c|}
\hline Priority & Source & $\begin{array}{c}\text { Mass of POPs, } \\
\text { g TEQ TCDD }\end{array}$ & $\begin{array}{c}\text { Percentage of total } \\
\text { input }\end{array}$ & $\begin{array}{c}\text { The actual number } \\
\text { of molecules per } \\
\text { capita }\end{array}$ & $\begin{array}{c}\text { The number of } \\
\text { molecules per } \\
\text { capita in the air }\end{array}$ \\
\hline 1 & Landfills & 34.05 & $87 \%$ & $6.31 \cdot 10^{16}$ & 0 \\
\hline 2 & Building materials & 2.864 & $7.32 \%$ & $5.31 \cdot 10^{15}$ & $4.48 \cdot 10^{15}$ \\
\hline 3 & Canalization & 2.00 & $5.11 \%$ & $3.7 \cdot 10^{15}$ & 0 \\
\hline 4 & Organic fuel & 0.22 & $0.56 \%$ & $4.08 \cdot 10^{14}$ & $4.08 \cdot 10^{14}$ \\
\hline 5 & Crematoria & 0.001 & Less $0.01 \%$ & $1.85 \cdot 10^{12}$ & $1.85 \cdot 10^{12}$ \\
\hline 6 & Cigarettes & 0.0003 & Less $0.01 \%$ & $5.56 \cdot 10^{11}$ & $5.56 \cdot 10^{11}$ \\
\hline & Total & 39.14 & $100 \%$ & $0.73 \cdot 10^{17}$ & $4.89 \cdot 10^{15}$ \\
\hline
\end{tabular}




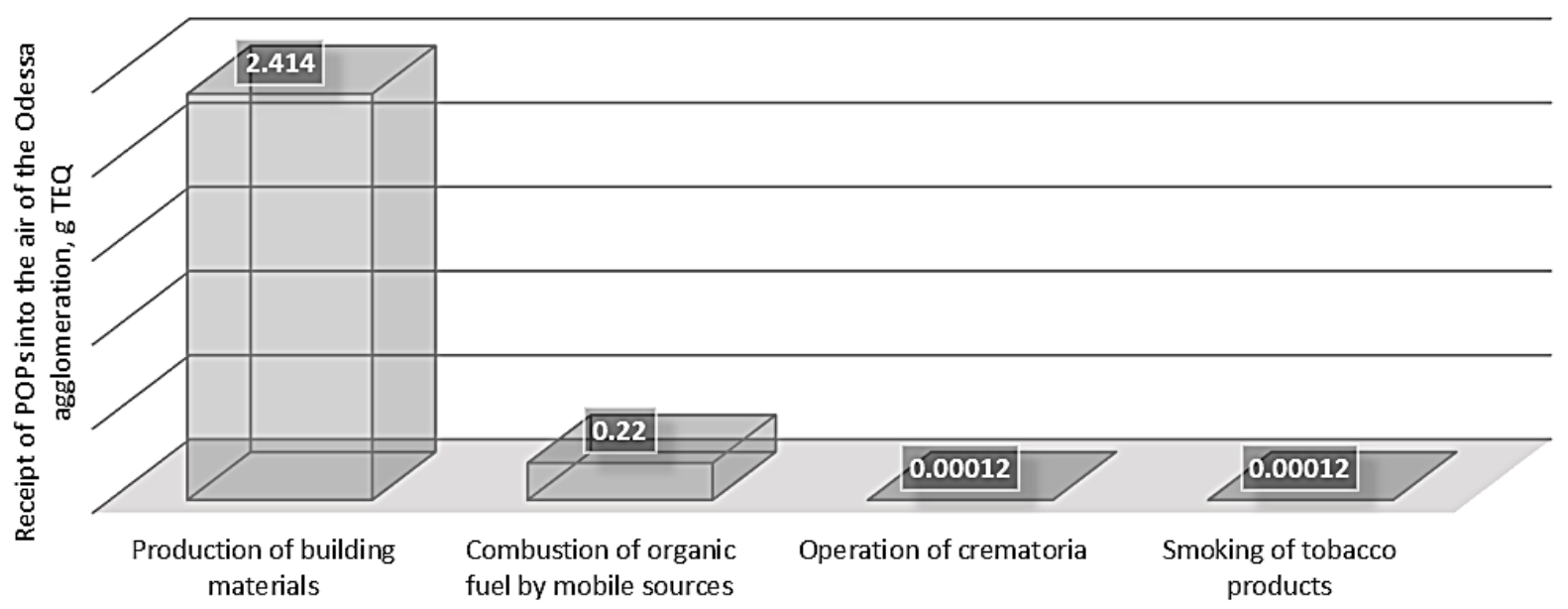

Figure 5. Receipt of POPs into the atmosphere in the Odessa agglomeration from the main sources

which enter the atmosphere was calculated, and it can be concluded that only the number of molecules of 2,3,7,8-TCDD per 1 inhabitant in atmospheric air of the Odessa agglomeration exceeds the permissible by almost 3 orders of magnitude for both years, which is unacceptable and requires measures to be taken to reduce POPs emissions (see Table 2). It should be noted that air pollution accounts for only $8 \%$ of all POPs, the other $92 \%$ are redistributed on soil and water environment.

\section{CONCLUSIONS}

As a result of the research, the following conclusions can be drawn:

- In the Odessa agglomeration, POPs are unintentionally formed from the following sources (in descending order): municipal solid waste deposits, production of building materials (bricks, cement and asphalt), functioning of municipal wastewater treatment plants, combustion of organic fuels from mobile sources, crematoriums and cigarette smoking. The combustion of organic fuels by mobile sources could not be taken into account due to the lack of initial information.

- The distribution of the load on the environments from the POPs in the Odessa agglomeration is: the main part of the POPs input into the soil environment with municipal solid waste, spent activated sludge and bricks $-89 \%$ of unintentionally formed POPs; about $8 \%$ of all POPs enter the air basin; about $3 \%$ of POPs enter the water environment.
- The main source of $\mathrm{PCDD} / \mathrm{F}$ is the storage of municipal solid waste in landfills, which accounts for about $87 \%$ of all sources of pollution. It should be noted that $\mathrm{PCDD} / \mathrm{F}$ from this source enters the soil, but some of it also enters water bodies.

- The main source of POPs in the air of Odessa agglomeration is the production of building materials (in the absence of data on the combustion of organic fuels by stationary sources). Even taking into account that the air contains only $8 \%$ of all POPs generated in the Odessa agglomeration, their number exceeds the allowable by 3 orders of magnitude.

- The main source of PCBs and HCBs in the environment is the production of building materials which makes the main contribution to the pollution of the air basin by POPs.

- Priority sources of the environmental pollution of the Odessa agglomeration have been identified, which allows taking timely measures to reduce the unintentional production of these substances. As can be seen from the results obtained, reducing the flow of municipal solid waste to landfills will significantly reduce the formation of these substances.

- The quality of statistical data is unsatisfactory, which is reflected in the noticeable incompleteness of the source information from the considered sources. This makes it impossible to obtain a complete, comprehensive picture of the unintentional production of POPs in the Odessa agglomeration.

- In order to clearly coordinate and take the operational measures to reduce the unintentional 
production of POPs, a separate legislative base and methodological framework for POPs should be developed in our country, which, unfortunately, does not exist today.

\section{REFERENCES}

1. Akhtar A., Yasar A., Naseem S., Naseem Z. 2021. Persistent Organic Pollutants (POPs): Sources, Types, Impacts, and Their Remediation. Environmental Pollution and Remediation, Environmental and Microbial Biotechnology, 213-246. DOI: 10.1007/978-981-15-5499-5_8

2. Chugai A.V., Safranov T.A., Lavrov T.V. 2020. Air quality formation factors of urban areas (with the example of the Odessa City). Ecologia Balkanica. 12(1), 57-65.

3. Collection of specific indicators of production and consumption waste generation. 1999. State Committee of the Russian Federation for Environmental Protection. 07.03.1999. https://meganorm.ru/ Data1/7/7041/index.htm

4. Cremation in Kiev, Kharkov and Odessa. 2012. https://www.religion.in.ua/news/ukrainian_ news/17968-v-kieve-kremiruyut-40-pokojnikovv-xarkove-70-v-odesse-30.html

5. EMEP/EEA air pollutant emission inventory guidebook. 2019. https://www.eea.europa.eu// publications/emep-eea-guidebook-2019

6. Exposure and Human Health Reassessment of 2,3,7,8-Tetrachlorodibenzo-p-Dioxin (TCDD) and Related Compounds National Academy Sciences (NAS) Review Draft. 2004. https://cfpub.epa.gov/ ncea/iris_drafts/dioxin/nas-review/index.cfm

7. GreenBud. Building materials. 2021. http://greenbud.kiev.ua/kirpich/kirpich-ryadovoj/kirpich-polnotelyj/kirpich-ryadovoj-polnotelyj-m-125.html

8. Gusev A., Rozovskaya O., Shatalov, Aas V., Nizzetto P. 2015. Assessment of spatial and temporal trends of POP pollution on regional and global scale. https:// www.researchgate.net/publication/288851152_Persistent_organic_pollutants_in_the_environment

9. International Agency for Research on Cancer. Agents Classifed by the IARC Monographs, 1-125. 2020. https://www.iarc.who.int/

10. International Agency for Research on Cancer. 2012. Chemical Agents and Related Occupations. A review of human carcinogens. Iarc Monographs on the Evaluation of Carcinogenic Risks to Humans, 100 F, France, 610.

11. Jeno J., Rathna R., Nakkeeran E. 2021. Biological Implications of Dioxins/Furans Bioaccumulation in Ecosystems. Environmental Pollution and Remediation, Environmental and Microbial Biotechnology, 213-246. DOI: 10.1007/978-981-15-5499-5_14
12. Kapushko M. 2012. On emissions of pollutants into the atmosphere at asphalt concrete plants. Internet Bulletin of VolgGASU, 8 (24). http://www.opengost. ru/iso/13_gosty_iso/13040_gost_iso/1304040_ gost_iso/3762-metodicheskie-ukazaniya-po-raschetu-vybrosov-zagryaznyayuschih-veschestv-vatmosferu-ot asfaltobetonnyh-zavodov.html

13. Kopytov V. 2012. Gasification of condensed fuels: a retrospective review, current state of affairs and development prospects. Moscow, Russia: Publishing "Infra-Engineering" (In Russian).

14. Malovanyy M., Nikiforov V., Kharlamova O., Synelnikov O. 2016. Production of renewable energy resources via complex treatment of cyanobacteria biomass. Chemistry \& Chemical Technology. 10(2), 251-254. DOI: $10.23939 /$ chcht10.02.251

15. Methodology for calculating emissions of harmful substances from enterprises of the road construction industry, including from asphalt concrete plants. 2008. The Ministry of Environmental Protection of the Republic of Kazakhstan, 18.04.2008 (In Russian).

16. Methodology for calculating waste generation standards in the production of bricks, reinforced concrete products, lime, asphalt. 1997. Ministry of Environmental Protection and Natural Resources of the Republic of Tatarstan. (In Russian).

17. Nykyforov V., Malovanyy M., Kozlovska T., Novokhatko O., Digtiar S. 2016. The biotechnological ways of blue-green algae complex processing. Eastern-European Journal of Enterprise Technologies.й. 5(10), 11-18. DOI: 10.15587/1729-4061.2016.79789.

18. Odessa cement plant. Wikipedia. Free encyclopedia. 2019. https://ru.wikipedia.org

19. Odnorih Z., Manko R., Malovanyy M., Soloviy K. 2020 Results of surface water quality monitoring of the western bug river Basin in Lviv Region. Journal of Ecological Engineering, 21(3), 18-26. DOI: 10.12911/22998993/118303

20. Ovidiopol brick factory LLC. Stroykeramika. 2021. https://stkeram.uaprom.net/

21. Pletos S. 2017. Trends suburbs greening urban agglomerations and economic development land use recreational Odessa conurbations. Global and national economic problems, 18, 396-401 (in Ukrainian). http://global-national.in.ua/archive/18-2017/76.pdf

22. Sakalova H., Malovanyy M., Vasylinycz T., Palamarchuk O., Semchuk J. 2019. Treatment of effluents from ions of heavy metals as display of environmentally responsible activity of modern businessman. Journal of Ecological Engineering, 20(4), 167-176. DOI: 10.12911/22998993/102841

23. Sale of construction and finishing materials: Dukat LV LLC. 2021. https://dukat-lv.prom.ua/

24. Self-regulatory organization in the field of energy inspection. Conversion calculator. 2021. 
https://sro150.ru/index.php/prochie-dokumenty/ kalkulyatory/287-kalkulyator-perevoda-v-t-u-t

25. Shelepchikov A. 2010. Environmental pollution by polychlorinated dibenzo-p-dioxins and dioxin-like substances. Laboratory of analytical ecotoxicology. http://www.dioxin.ru/history/

26. Statistical worker of the Odessa region. 2012. Head of the Department of Statistics in the Odessa region. http://www.od.ukrstat.gov.ua/

27. Statistical worker of the Odessa region. 2017. Head of the Department of Statistics in the Odessa region. http://www.od.ukrstat.gov.ua/

28. The number of smokers in Ukraine has decreased. ZN.UA. https://zn.ua/UKRAINE/kolichestvokurilschikov-v-ukraine-za-sem-let-sokratilosna-20-259009_html

29. Treger Yu. 2011. Persistent Organic Pollutants. Problems and ways of their solution, Vestnik
MITHT, 5(6), 87-97. (In Russian).

30. Ukrainian Ministry. (2019). Some Questions of state monitoring in the field of atmospheric air protection. Decree \#827 from 14.09.2019, Kiev, Ukraine. Retrieved from zakon.rada.gov.ua

31. UNEP. 2013. Toolkit for Identification and Quantification of Releases of Dioxins, Furans and Other Unintentional POPs. Retrieved from http://toolkit.pops.int/ publish/downloads/unep-pops-toolkit-2012-en.pdf

32. VanEtten S.L., Bonner M.R., Ren X., et al. 2020. Telomeres as targets for the toxicity of 2,3,7,8-tetrachlorodibenzo-p-dioxin (TCDD) and polychlorinated biphenyls (PCBs) in rats, Toxicology and Applied Pharmacology. DOI: 10.1016/j.taap.2020.115264

33. Xu W., et al. 2013. Analytical chemistry of the persistent organic pollutants identified in the Stockholm Convention: A review, Anal. Chim. Acta. DOI: 10.1016/j.aca.2013.04.026 